\title{
Dual Antiplatelet Therapy in Coronary Artery Disease
}

\author{
Raghav Sharma $\cdot$ Prathap Kumar $\cdot$ S. P. Prashanth $\cdot$ Yogesh Belagali
}

Received: July 15, 2020 / Published online: August 17, 2020

(C) The Author(s) 2020

\section{ABSTRACT}

Acute coronary syndrome (ACS) is principally driven by platelet aggregation. Dual antiplatelet therapy (DAPT) has demonstrated a reduction in recurrent ischemic events. The newer antiplatelets ticagrelor and prasugrel have demonstrated superiority over clopidogrel. While prasugrel demonstrated benefit in patients scheduled for percutaneous intervention (PCI), benefits of ticagrelor were seen irrespective of the treatment strategy. Current guidelines recommend the use of DAPT for 1 year in all patients with ACS. Ticagrelor $60 \mathrm{mg}$ is recommended for up to 3 years in high-risk patients. DAPT and Predicting Bleeding Complications in Patients

Digital Features To view digital features for this article go to https://doi.org/10.6084/m9.figshare.12753119.

Electronic supplementary material The online version of this article (https://doi.org/10.1007/s40119. 020-00197-0) contains supplementary material, which is available to authorized users.

\section{R. Sharma}

Interventional Cardiologist, Meditrina Hospital

Civil Hospital, Ambala Cantt, Haryana, India

P. Kumar

Interventional Cardiologist, Meditrina Hospital, Ayoor road, Ayathil, Kollam, Kerala, India

S. P. Prashanth · Y. Belagali $(\bowtie)$

Medical Affairs Division, AstraZeneca, Rachenahalli, Bangalore, India

e-mail: yogesh.belagali@astrazeneca.com
Undergoing Stent Implantation and Subsequent Dual Antiplatelet Therapy (PRECISE DAPT) scores are tools to support decision-making in deciding duration of dual antiplatelet therapy.

Keywords: Clopidogrel; Coronary artery disease; Dual antiplatelet therapy; Prasugrel; Switching between antiplatelets; Ticagrelor

\section{Key Summary Points}

Acute coronary syndrome (ACS) is principally driven by platelet aggregation. Dual antiplatelet therapy (DAPT) has demonstrated a reduction in recurrent ischemic events.

The newer antiplatelets ticagrelor and prasugrel have demonstrated superiority over clopidogrel. While prasugrel demonstrated benefit in patients scheduled for percutaneous intervention (PCI), benefits of ticagrelor were seen irrespective of the treatment strategy.

Current guidelines recommend the use of DAPT for 1 year in all patients with ACS. Ticagrelor $60 \mathrm{mg}$ is recommended for up to 3 years in high-risk patients. DAPT and PRECISE DAPT scores are tools to support decision-making in deciding duration of dual antiplatelet therapy. 


\section{INTRODUCTION}

Coronary artery disease (CAD) and ACS together account for approximately 7 million deaths each year [1]. Ischemic heart disease (IHD) is the single greatest cause of mortality and loss of disability adjusted life years (DALYs) worldwide, which accounts for roughly 7 million deaths and 129 million DALYs annually. IHD and acute coronary syndrome (ACS) are the leading causes of death, on average, at younger ages and at economically productive ages in low- and middle-income countries (LMICs) than in high-income countries [2]. ACS, which accounts for around half of global burden, is the leading cause of mortality in the Asia-Pacific region [3]. This article is based on previously conducted studies and does not contain any studies with human participants or animals performed by any of the authors.

\section{Pharmacology of Currently Available Antiplatelet Drugs}

Thrombus formation in ACS is principally driven by platelet aggregation [4]. In patients with $\mathrm{CAD}$, there is a central role played by platelet inhibition in both treatment and prevention of short as well as long-term atherothrombotic events. Oral antiplatelet agents recommended for secondary prevention include the cyclooxygenase- 1 inhibitor aspirin, and the platelet adenosine diphosphate P2Y12 receptor inhibitors clopidogrel, prasugrel, and ticagrelor [5].

Among several potential combinations of antiplatelet agents, DAPT refers to the combination of aspirin and a P2Y12 receptor inhibitor. DAPT has been shown to reduce recurrent major ischemic events in patients with ACS [5]. Table 1 demonstrates the pharmacological properties of currently used antiplatelet drugs.

\section{Pivotal Clinical Trials of DAPT in ACS}

The standard 1-year recommendation for DAPT is based on the experiences from the duration of P2Y12 inhibition in pivotal early antiplatelet trials, such as CURE. In patients treated with
Table 1 Pharmacological properties of currently used antiplatelets

\begin{tabular}{|c|c|c|c|}
\hline Drug & $\begin{array}{l}\text { Clopidogrel } \\
{[6]}\end{array}$ & $\begin{array}{l}\text { Prasugrel } \\
{[7]}\end{array}$ & $\begin{array}{l}\text { Ticagrelor } \\
{[8]}\end{array}$ \\
\hline Prodrug & Yes & Yes & No \\
\hline $\begin{array}{l}\text { Route of } \\
\text { administration }\end{array}$ & Oral & Oral & Oral \\
\hline Onset of action & $2-6 h$ & $30 \mathrm{~min}$ & $30 \mathrm{~min}$ \\
\hline $\begin{array}{l}\text { Duration of } \\
\text { action }\end{array}$ & $3-10$ days & $7-10$ days & 3-5 days \\
\hline Loading dose & $300-600 \mathrm{mg}$ & $60 \mathrm{mg}$ & $180 \mathrm{mg}$ \\
\hline $\begin{array}{l}\text { Maintenance } \\
\text { dose }\end{array}$ & $75 \mathrm{mg}$ OD & $\begin{array}{r}10 \mathrm{mg} \\
\mathrm{OD}\end{array}$ & $90 \mathrm{mg}$ BD \\
\hline $\begin{array}{l}\text { Withdrawal } \\
\text { before surgery }\end{array}$ & 5 days & 7 days & 5 days \\
\hline
\end{tabular}

first-generation drug-eluting stent (DES), premature discontinuation of DAPT was associated with reports of late stent thrombosis. This prompted the empirical recommendation in these patients to prolong DAPT duration for up to 12 months [9].

The CURE study demonstrated a significant reduction of the primary composite endpoint (cardiovascular (CV) death, non-fatal MI or stroke) in clopidogrel plus aspirin arm compared with aspirin alone at 12 months (9.3 vs. $11.4 \%, \quad \mathrm{RR}=0.80, \quad 95 \% \quad \mathrm{CI}=0.72-0.90$, $p<0.001$ ), with an increased risk of major bleeding (3.7 vs. $2.7 \%, \mathrm{RR}=1.38, p=0.001)$ in 12,262 patients with NSTE- ACS, however there was no significant difference in the mortality between treatment groups ( 5.1 vs. $5.5 \%, \mathrm{HR}=$ 0.93, 95\% CI $=0.79-1.08$ ) [7].

The TRITON-TIMI conducted in 13,608 patients with moderate-to-high-risk ACS scheduled to undergo PCI demonstrated that prasugrel significantly reduced the risk of the primary composite endpoint (CV death, non-fatal MI, or stroke) by $19 \%$ (9.9 vs. $12.1 \%, \mathrm{HR}=0.81,95 \%$ $\mathrm{CI}=0.73-0.90)$, $\mathrm{MI}$ by $24 \%$ (7.3 vs. $9.5 \%, \mathrm{HR}=$ $0.76,95 \% \mathrm{CI}=0.67-0.85)$ compared to clopidogrel, but increased the risk of non CABG-related major bleeding ( 2.4 vs. $1.8 \%, \mathrm{HR}=1.32$, 
95\% CI $=1.03-1.6, p=0.03)$, including fatal bleeding. However, there was no significant difference in the mortality between treatment groups $(3.0$ vs. $3.2 \%, \quad \mathrm{HR}=0.95, \quad 95 \%$ $\mathrm{CI}=0.78-1.16, p=0.64)$. In a post hoc subgroup analysis of patients with age $\geq 75$ years, bodyweight $<60 \mathrm{~kg}$ or history of stroke or transient ischemic attack (TIA), prasugrel was associated with reduced clinical benefit regarding the primary efficacy endpoint along with increased risk of bleeding [10].

The TRILOGY ACS study showed no clear benefit of prasugrel over clopidogrel in medically managed ACS patients [11].

The PLATO study compared ticagrelor with clopidogrel in addition to aspirin in 18,624 patients with ACS. At a follow-up of 12 months, ticagrelor significantly reduced the risk of the primary composite endpoint (CV death, nonfatal MI, or stroke) by $16 \%$ (9.8 vs. $11.7 \%$, HR $0.84,95 \%$ CI $0.77-0.92, p<0.001)$, MI by $16 \%$ (5.8 vs. $6.9 \%$, HR $0.84,95 \%$ CI $0.75-0.95$, $p=0.005$ ), all-cause mortality (4.5 vs. $5.9 \%$, HR $0.78,95 \%$ CI $0.69-0.89, p<0.001)$ and CV mortality (4.0 vs. 5.1\%, HR $0.79,95 \%$ CI $0.69-0.91, p=0.001$ ) by 22 and $21 \%$, respectively. No significant difference was observed in the overall incidence of major bleeding (11.6 vs. $11.2 \%$, HR 1.04, 95\% CI 0.95-1.13, $p=0.43$ ). However, ticagrelor was associated with a higher rate of major bleeding not related to coronary-artery bypass grafting ( 4.5 vs. $3.8 \%$, $p=0.03)$ [12]. The benefits of ticagrelor were independent of whether an invasive strategy was planned and have been validated in a realworld setting using large-scale registry data [13].

\section{DAPT Beyond 12 Months: Clinical Evidence}

The risk of MI, stroke, and all-cause death is consistently high in chronic-phase post MI raising consistently up to 3 years, as shown in the APOLLO real-world evidence study, which included 114,364 patients from across four countries [14]. Hence, many studies have attempted to evaluate benefits of DAPT beyond 12 months.

CHARISMA was one of the first trials that evaluated the long-term use of clopidogrel plus aspirin as compared with aspirin alone in 15,630 patients at high risk for a cardiovascular event. The trial failed to demonstrate any significant benefits of prolonged DAPT in reducing the rate of MI, stroke, or death from cardiovascular causes at a median duration of 28 months and suggested harm in terms of bleeding in patients with multiple risk factors [15].

The PEGASUS-TIMI 54 was a randomized trial that evaluated two doses of ticagrelor $(90$ or $60 \mathrm{mg}$ twice daily) plus aspirin to aspirin alone, in 21,162 stable ACS patients (MI 1-3 years earlier,) at high risk and followed up for a median of 33 months. The results demonstrated that prolonged DAPT with either dose of ticagrelor reduced ischemic events (for $60 \mathrm{mg}$ dose $\mathrm{HR}=0.84 ; 95 \%$ CI $0.74-0.95 ; p=0.004)$ MACE compared to aspirin alone [HR 0.85 (95\% CI: $0.75-0.96), p=0.008]$. As anticipated, major bleeding with ticagrelor increased $(2.69 \%$ for ticagrelor $90 \mathrm{mg}$ vs. $2.32 \%$ for ticagrelor $60 \mathrm{mg}$ vs. $1.0 \%$ for aspirin alone), however, there was no significant difference between fatal bleeding or nonfatal intracranial hemorrhage between either ticagrelor dose group and placebo [16].

In the DAPT study, extension of DAPT using thienopyridines (either clopidogrel or prasugrel) with aspirin was evaluated up to 30 months after PCI in 9961 patients who received a DES. It was the first study that showed a significant reduction in MI from both target and non-target lesions, suggesting a secondary preventive effect of prolonging DAPT. It also showed a significant reduction in stent thrombosis [0.4 vs. $1.4 \%$; HR, $0.29 \quad 95 \%$ CI $0.17-0.48)$; $p<0.001]$, MI $(2.1$ vs. $4.1 \%$; HR, 0.47 ; $p<0.001)$ and MACE [0.3 vs. $5.9 \%$; HR, 0.71 (95\% CI 0.59-0.85); $p<0.001]$ but no significant benefit in reduction of all-cause mortality and stroke. Prolonging DAPT was also associated with an increase in moderate to severe bleeding (2.5 vs. $1.6 \%, p=0.001$ ) [17].

\section{Upcoming Evidence of Monotherapy With P2Y12 Inhibitors}

The non-inferiority STOPDAPT-2 trial of 3045 patients who underwent PCI were randomized to receive either 1-month DAPT followed by 
Table 2 Recommendations on switching of P2Y12 inhibitors [10, 12]

\begin{tabular}{|c|c|c|c|c|c|c|}
\hline \multirow[t]{3}{*}{ From } & \multicolumn{6}{|c|}{ To } \\
\hline & \multicolumn{3}{|c|}{ Acute Setting ${ }^{\mathrm{a}}$} & \multicolumn{3}{|c|}{ Chronic Setting $^{\mathrm{b}}$} \\
\hline & $\begin{array}{l}\text { Clopidogr } \\
\text { el }\end{array}$ & Prasugrel & $\begin{array}{l}\text { Ticagrel } \\
\text { or }\end{array}$ & $\begin{array}{l}\text { Clopidogr } \\
\text { el }\end{array}$ & Prasugrel & Ticagrelor \\
\hline $\begin{array}{l}\text { Clopidogr } \\
\text { el }\end{array}$ & - & $\begin{array}{l}\text { Prasugrel } \\
60 \mathrm{mg} \\
\text { LD } \\
\text { (irrespect } \\
\text { ive of } \\
\text { prior } \\
\text { clopidog } \\
\text { rel } \\
\text { timing } \\
\text { and } \\
\text { dosing) }\end{array}$ & $\begin{array}{c}\text { Ticagrel } \\
\text { or } 180 \\
\text { mg LD } \\
\text { (irrespect } \\
\text { ive of } \\
\text { prior } \\
\text { clopidog } \\
\text { rel } \\
\text { timing } \\
\text { and } \\
\text { dosing) }\end{array}$ & - & $\begin{array}{l}\text { Prasugrel } \\
10 \text { mg o.d } \\
\text { MD (24 h } \\
\text { after last } \\
\text { Clopidogr } \\
\text { el dose) }\end{array}$ & $\begin{array}{l}\text { Ticagrelor } \\
90 \text { mg b.d } \\
\text { MD (24 h } \\
\text { after last } \\
\text { Clopidogr } \\
\text { el dose) }\end{array}$ \\
\hline Prasugrel & $\begin{array}{c}\text { Clopidogr } \\
\text { el } 600 \mathrm{mg} \\
\text { LD }(24 \mathrm{~h} \\
\text { after } \\
\text { Prasugrel } \\
\text { dose })\end{array}$ & - & $\begin{array}{c}\text { Ticagrel } \\
\text { or } 180 \\
\text { mg LD } \\
(24 \mathrm{~h} \\
\text { after } \\
\text { Prasugrel } \\
\text { dose) }\end{array}$ & $\begin{array}{c}\text { Clopidogr } \\
\text { el } 75 \mathrm{mg} \\
\text { o.d MD } \\
\text { (24 h after } \\
\text { last } \\
\text { Prasugrel } \\
\text { dose) }\end{array}$ & - & $\begin{array}{c}\text { Ticagrelor } \\
90 \text { mg b.d } \\
\text { MD (24 h } \\
\text { after last } \\
\text { Prasugrel } \\
\text { dose) }\end{array}$ \\
\hline Ticagrelor & $\begin{array}{c}\text { Clopidogr } \\
\text { el } 600 \mathrm{mg} \\
\mathrm{LD}(24 \mathrm{~h} \\
\text { after } \\
\text { Ticagrelor } \\
\text { dose })\end{array}$ & $\begin{array}{c}\text { Prasugrel } \\
60 \mathrm{mg} \\
\text { LD }(24 \mathrm{~h} \\
\text { after } \\
\text { Ticagrel } \\
\text { or dose }) \\
\end{array}$ & - & $\begin{array}{c}\text { Clopidogr } \\
\text { el } 600 \mathrm{mg} \\
\mathrm{LD}(24 \mathrm{~h} \\
\text { after } \\
\text { Ticagrelor } \\
\text { dose })\end{array}$ & $\begin{array}{c}\text { Prasugrel } \\
60 \text { mg LD } \\
\text { (24 h after } \\
\text { Ticagrelor } \\
\text { dose) }\end{array}$ & - \\
\hline
\end{tabular}

$L D$ loading dose, $M D$ maintenance dose, $o . d$ once daily, $b . d$ twice daily

clopidogrel monotherapy $(n=1523)$ or 12-months DAPT with aspirin and clopidogrel $(n=1522)$. One-month DAPT was found to be both non-inferior as well as superior to 12-month DAPT with primary endpoint (composite of cardiovascular death, myocardial infarction (MI), ischemic or hemorrhagic stroke, definite stent thrombosis, or major or minor bleeding at 12 months) occurring in $2.36 \%$ compared to $3.70 \%$ in the 12 -month DAPT arm (HR $0.64, p<0.001$ for non-inferiority and $p=0.04$ for superiority). Major or minor bleeding occurred less in the 1-month DAPT arm than in the 12-month DAPT arm (0.41 vs. $1.54 \%$, HR $0.26, p=0.004$ for superiority) [18].
Another non-inferiority SMART-CHOICE trial evaluated the use of short-term DAPT of 3 months compared to 12 months. Here, 2993 patients who underwent PCI with DUS were randomized to receive 3 months of DAPT with P2Y12 inhibitor plus aspirin followed by P2Y12 inhibitor alone or DAPT for 12 months. The primary endpoint (composite of all-cause death, myocardial infarction, or stroke at 12 months) was more in the monotherapy group than the 12 months DAPT group (2.9 vs. $2.5 \%, 95 \%$ CI $\infty-1.3 \%, p=0.007$ for non-inferiority). The bleeding rates were significantly lower in the monotherapy group than in the DAPT group (2.0 vs. 3.4\%; HR, 0.58; $p=0.02$ ) [19]. 
The GLOBAL-LEADERS trial was conducted on 15,968 patients undergoing PCI with a Biolimus A9-eluting stent for stable CAD or ACS. Patients received 75-100 mg aspirin daily plus $90 \mathrm{mg}$ ticagrelor twice daily for 1 month, followed by 23 months of ticagrelor monotherapy, or standard DAPT with 75-100 mg aspirin daily plus either $75 \mathrm{mg}$ clopidogrel daily (for patients with stable CAD) or $90 \mathrm{mg}$ ticagrelor twice daily (for patients with ACS) for 12 months, followed by aspirin monotherapy for 12 months. The composite of all-cause mortality or non-fatal centrally adjudicated new Q-wave MI at the end of 2 years was 3.81 vs. $4.93 \%$ [RR 0.87 (95\% CI $0.75-1.01) ; p=0.073)]$. Grade 3 or 5 bleeding was 2.04 vs. $2.12 \%$ [RR 0.97 (95\% CI $0.78-1.20$ ); $p=0.77]$. The study failed to show superiority of ticagrelor monotherapy over standard DAPT [20].

In the TWILIGHT Trial, 7119 patients after 3 months of DAPT with aspirin and ticagrelor were randomized to receive either ticagrelor $90 \mathrm{mg}$ BD plus placebo or DAPT in the form of ticagrelor $90 \mathrm{mg}$ BD plus aspirin $81-100 \mathrm{mg}$ daily for the next 12 months and followed up to 18 months. The primary endpoint BARC type 2,3 or 5 Bleeding was 4.0 vs. $7.1 \%$ for monotherapy compared to DAPT (HR 0.56;95\% CI $0.45-0.68 ; p<0.001)$. BARC type 3 or 5 bleeding was similar among both of the groups ( 1 vs. $2 \%$ for monotherapy compared to DAPT, (HR 0.49, 95\% CI 0.33-0.74). Ticagrelor monotherapy was noninferior to DAPT in terms of incidence of death from any cause, nonfatal MI or nonfatal stroke $3.9 \%$ in both groups, \%difference - 0.06, 95\% CI 0.78-1.25; $p<0.001$ for noninferiority). The study showed that ticagrelor monotherapy after 3 months of completed DAPT was associated with lower incidence of clinically relevant bleeding than DAPT with no higher risk of MI, stroke, or death [21].

The TICO trial evaluated whether switching to ticagrelor monotherapy after 3 months of DAPT reduces adverse clinical events compared to 12 months of DAPT. Patients with ACS treated with DUS $(n=3056)$ were randomized to receive either ticagrelor $90 \mathrm{mg} \mathrm{BD}$ monotherapy after 3 months of DAPT $(n=1527)$ or 12 months of ticagrelor-based DAPT $(n=1529)$.
The primary endpoint (composite of major bleeding and adverse cardiac and cerebrovascular events of death, myocardial infarction, stent thrombosis, stroke, or target-vessel revascularization) occurred in $3.9 \%$ of patients receiving monotherapy compared to $5.9 \%$ in the 12-month DAPT group (HR 0.66, $p=0.01$ ). Major bleeding was less in the monotherapy group compared to the 12-month DAPT group (1.7 vs. $3.0 \%, \mathrm{HR}=0.56, p=0.02)$. The incidence of major adverse cardiac and cerebrovascular events was not significantly different between the two groups (2.3 vs. 3.4\%, HR 0.69, $p=0.09$ ). The study concluded that ticagrelor monotherapy after 3 months of DAPT offered modest but significant reduction in composite of major bleeding and cardiovascular events at 1 year compared to 12 months of DAPT [22].

\section{Pivotal Clinical Trials in Stable CAD}

CHARISMA was one of the first trials that evaluated the long-term use of clopidogrel plus aspirin as compared with aspirin alone in 15,630 patients at high risk for a cardiovascular event. The trial failed to demonstrate any significant benefit of prolonged DAPT in reducing the rate of MI, stroke, or death from cardiovascular causes at a median duration of 28 months and suggested harm in terms of bleeding in patients with multiple risk factors [15].

In the THEMIS trial, 19,220 patients $\geq 50$ with type 2 diabetes and stable $\mathrm{CAD}$ and no history of previous MI or stroke were randomly assigned to receive either ticagrelor plus aspirin or placebo plus aspirin, with a median followup of 39.9 months. The primary endpoint, a composite of $\mathrm{CV}$ death Mi or stroke, was lower in the ticagrelor group than in the placebo group (7.7 vs. 8.5\%; HR 0.90; 95\% CI 0.81-0.99; $p=0.04)$. The incidence of primary safety endpoint TIMI major bleeding was higher in the ticagrelor group than in placebo group (2.2 vs. 1.0\%; HR 2.32; 95\% CI 1.82-2.94; $p<0.001)$. Incidence of ICH was higher in the ticagrelor group (0.7 vs. $0.5 \%$; HR $1.71 ; 95 \%$ CI $1.18-2.48$; $p=0.005)$ but there was no significant difference in incidence of fatal bleeding. The study concluded that in patients with stable CAD and 
diabetes without a history of MI or stroke, using ticagrelor with aspirin lowered the incidence of ischemic cardiovascular events but had a higher incidence of major bleeding than those who received placebo plus aspirin [23].

In the THEMIS PCI trial, a prespecified subgroup of 11,154 patients (58\% of the THEMIS population) having a history of previous PCI were analyzed. The primary endpoint, composite of CV death, MI, or stroke was $7.3 \%$ in the ticagrelor group compared to $8.6 \%$ in the placebo group (HR 0.85, 95\% CI 0.74-0.97, $p=0.013)$. TIMI major bleed occurred in $2 \%$ of patients in the ticagrelor arm vs. $1.1 \%$ in the placebo arm (HR 2.03, 95\% CI 1.48-2.76, $p<0.0001)$. Fatal bleed and ICH occurrence were similar in both groups. Patients with PCI had a better net clinical benefit compared to those without PCI (9.3 vs. $11.0 \%, \mathrm{HR}=0.85$, $95 \%$ CI $0.75-0.95, p=0.005)$ and benefit was present irrespective of time from most recent PCI [24].

\section{Choosing The Appropriate P2Y12 Inhibitor}

In the multicenter randomized PRAGUE 18 study, head-to-head comparison of efficacy and safety was attempted between prasugrel and ticagrelor in 1230 patients with acute MI treated with PCI. However, the study was terminated prematurely due to futility. The primary endpoint, which is a composite of all-cause death, reinfarction, stroke, serious bleeding requiring transfusion or prolonging hospitalization, or urgent target-vessel revascularization within 7 days after randomization or at discharge if before the 7th day, was similar between both groups $(4.0 \%$ with prasugrel and $4.1 \%$ with ticagrelor, OR 0.98 ; 95\% CI $0.55-1.73$; $p=0.939$ ). The secondary endpoint at 30 days, which is cardiovascular death, nonfatal myocardial infarction, or stroke, was also not significantly different between the two groups (2.7 and 2.5\%, respectively; OR 1.06; 95\% CI $0.53-2.15 ; p=0.864$ ) [25].

The ISAR REACT 5 trial was a multicenter, randomized, open-label trial on 4018 ACS patients who were randomly assigned to receive either prasugrel loading dose of $60 \mathrm{mg}$, followed by $10 \mathrm{mg}$ OD, or ticagrelor loading dose of $180 \mathrm{mg}$ as soon as possible, followed by $90 \mathrm{mg}$ $\mathrm{BD}$. However, in the prasugrel group, the timing of administration of trial drug depended on clinical presentation with the drug being administered as soon as possible to ST elevation ACS patients and for patients without ST elevations loading dose was deferred until coronary anatomy was known. The primary endpoint, composite of MI, stroke, or death, was $9.3 \%$ in the ticagrelor group compared to $6.9 \%$ in the prasugrel group (HR 1.36, 95\% CI $1.09-1.70 ; p=0.006)$. Major bleed defined by the BARC scale was $5.4 \%$ in the ticagrelor arm compared to $4.8 \%$ in the prasugrel arm (HR $1.12 ; 95 \%$ CI $0.83-1.51 ; p=0.46)$ [26].

\section{Ideal Patient Profile For DAPT Beyond 12 Months}

Factors associated with an increased risk of ischemic events include recent ACS, prior MI, diabetes, complex coronary lesions, and procedural aspects, while a history of bleeding is the principal risk factor for bleeding events. The tools to support decision-making are the DAPT study score and the Predicting Bleeding Complications in Patients Undergoing Stent Implantation and Subsequent Dual Antiplatelet Therapy (PRECISE-DAPT) score. A high DAPT score $\geq 2$ in patients who have received a 12-month course of DAPT without experiencing ischemic or bleeding events, favors prolongation to 30 months. Conversely, a high PRECISEDAPT score of $\geq 25$ at the index event signifies a high risk of bleeding and a potential benefit from shortened DAPT duration [16]. The Patterns of non-Adherence to Anti-Platelet Regimen in Stented Patients (PARIS) thrombotic risk score predicts the risk of coronary thrombotic events after percutaneous coronary intervention (PCI) that consists of six factors, including acute coronary syndrome (ACS), current smoking, diabetes mellitus, creatinine clearance $<60 \mathrm{ml} / \mathrm{min}$, prior PCI, and prior coronary artery bypass grafting (CABG). The prognostic value for PARIS risk score of mortality is better than that of MACCE [27]. ARC 
Table 3 Management of bleeding during triple therapy [30]

\begin{tabular}{|c|c|c|c|c|}
\hline \multicolumn{5}{|c|}{ Bleeding during triple therapy } \\
\hline Bleeding & Definition & $\begin{array}{l}\text { DAPT } \\
\text { management }\end{array}$ & OAC management & $\begin{array}{l}\text { General } \\
\text { management }\end{array}$ \\
\hline Trivial & $\begin{array}{l}\text { Bleeding not requiring medical } \\
\text { intervention or further evaluation }\end{array}$ & Continue & Consider continuation & $\begin{array}{l}\text { Reassurance } \\
\text { Identify possible } \\
\text { preventive } \\
\text { strategies } \\
\text { Counsel on } \\
\text { importance of drug } \\
\text { adherence }\end{array}$ \\
\hline Mild & $\begin{array}{l}\text { Requires medical intervention but } \\
\text { without hospitalization }\end{array}$ & $\begin{array}{l}\text { Continue } \\
\text { Consider shortening } \\
\text { DAPT duration } \\
\text { Consider switching } \\
\text { to less potent } \\
\text { P2Y12 }\end{array}$ & $\begin{array}{l}\text { Downgrade to DAPT } \\
\text { (preferably } \\
\text { OAC }+ \text { clopidogrel })\end{array}$ & $\begin{array}{l}\text { Identify and treat } \\
\text { risk factors } \\
\text { Add PPI if not } \\
\text { started } \\
\text { Counsel on } \\
\text { importance of drug } \\
\text { adherence }\end{array}$ \\
\hline Moderate & $\begin{array}{l}\text { Bleeding associated with significant } \\
\text { blood loss }(>3 \mathrm{~g} / \mathrm{dl} \mathrm{HB}) \text { and/or } \\
\text { requiring hospitalization } \\
\text { (hemodynamically stable, not } \\
\text { evolving) }\end{array}$ & $\begin{array}{l}\text { Consider stopping } \\
\text { DAPT } \\
\text { Switch to single } \\
\text { APT (P2Y12 } \\
\text { inhibitor) } \\
\text { Reinitiate DAPT as } \\
\text { soon as considered } \\
\text { safe } \\
\text { Consider shortening } \\
\text { DAPT duration } \\
\text { Consider switching } \\
\text { to less potent } \\
\text { P2Y12 }\end{array}$ & $\begin{array}{l}\text { Discontinue/reverse } \\
\text { OAC unless very } \\
\text { high thrombotic risk } \\
\text { Reinitiate within } \\
1 \text { week if clinically } \\
\text { indicated } \\
\text { Downgrade to DAPT } \\
\text { (preferably } \\
\text { OAC + clopidogrel) } \\
\text { If on DAPT and } \\
\text { deemed safe, consider } \\
\text { stopping APT }\end{array}$ & $\begin{array}{l}\text { Consider IV PPI if } \\
\text { GI bleed occurred } \\
\text { Identify and treat } \\
\text { risk factors } \\
\text { Counsel on } \\
\text { importance of drug } \\
\text { adherence }\end{array}$ \\
\hline
\end{tabular}


Table 3 continued

\begin{tabular}{|c|c|c|c|c|}
\hline \multicolumn{5}{|c|}{ Bleeding during triple therapy } \\
\hline Bleeding & Definition & $\begin{array}{l}\text { DAPT } \\
\text { management }\end{array}$ & OAC management & $\begin{array}{l}\text { General } \\
\text { management }\end{array}$ \\
\hline Severe & $\begin{array}{l}\text { Requiring hospitalization } \\
\text { Severe blood loss (>5 g/dl HB) } \\
\text { (Hemodynamically stable, not } \\
\text { evolving) }\end{array}$ & $\begin{array}{l}\text { Consider stopping } \\
\text { DAPT } \\
\text { Switch to single } \\
\text { APT (P2Y12 } \\
\text { inhibitor) } \\
\text { If bleeding persists, } \\
\text { consider stopping } \\
\text { all antithrombotic } \\
\text { medications } \\
\text { Once bleeding } \\
\text { stops, re-evaluate } \\
\text { need for DAPT/ } \\
\text { SAPT } \\
\text { If DAPT is } \\
\text { required, consider } \\
\text { shortening DAPT } \\
\text { duration } \\
\text { Consider switching } \\
\text { to less potent } \\
\text { P2Y12 }\end{array}$ & $\begin{array}{l}\text { Discontinue/reverse } \\
\text { OAC unless very } \\
\text { high thrombotic risk } \\
\text { Reinitiate within } 1 \\
\text { week if clinically } \\
\text { indicated } \\
\text { Downgrade to DAPT } \\
\text { (preferably } \\
\text { OAC + clopidogrel) }\end{array}$ & $\begin{array}{l}\text { Consider IV PPI if } \\
\text { GI bleed occurred } \\
\text { RBC transfusion if } \\
\mathrm{HB}<7-8 \mathrm{~g} / \mathrm{dl} \\
\text { Consider platelet } \\
\text { transfusion } \\
\text { Urgent endoscopic } \\
\text { or surgical } \\
\text { treatment of } \\
\text { bleeding source if } \\
\text { possible }\end{array}$ \\
\hline $\begin{array}{l}\text { Life- } \\
\text { threatening }\end{array}$ & $\begin{array}{l}\text { Severe bleeding putting patient's life } \\
\text { immediately at risk }\end{array}$ & $\begin{array}{l}\text { Immediately } \\
\text { discontinue all } \\
\text { antithrombotic } \\
\text { medications } \\
\text { Once bleeding } \\
\text { stops, re-evaluate } \\
\text { need for DAPT/ } \\
\text { SAPT } \\
\text { If DAPT is } \\
\text { required, consider } \\
\text { shortening DAPT } \\
\text { duration } \\
\text { Consider switching } \\
\text { to less potent } \\
\text { P2Y12 }\end{array}$ & Stop and reverse & $\begin{array}{l}\text { Fluid replacement } \\
\text { Consider RBC } \\
\text { transfusion } \\
\text { irrespective of HB } \\
\text { levels } \\
\text { Platelet transfusion } \\
\text { Consider IV PPI if } \\
\text { GI bleed occurred } \\
\text { Urgent endoscopic } \\
\text { or surgical } \\
\text { treatment of } \\
\text { bleeding source if } \\
\text { possible }\end{array}$ \\
\hline
\end{tabular}


Table 4 Guideline recommendations on use of antiplatelets [40, 41]

\begin{tabular}{|c|c|c|c|c|}
\hline Recommendation & $\mathrm{ESC}$ & Evidence & AHA & Evidence \\
\hline $\begin{array}{l}\mathrm{P} 2 \mathrm{Y} 12- \\
\text { antagonist }\end{array}$ & $\begin{array}{l}\text { All ACS patients-12 } \\
\text { months }\end{array}$ & Class I & $\begin{array}{l}\text { All ACS patients-at least } 12 \\
\text { months }\end{array}$ & Class I \\
\hline \multirow[t]{4}{*}{$\begin{array}{l}\text { Choice of } \\
\text { P2Y12- } \\
\text { antagonist }\end{array}$} & $\begin{array}{l}\text { Ticagrelor preferred over } \\
\text { clopidogrel, irrespective } \\
\text { of initial treatment } \\
\text { strategy }\end{array}$ & Class I & $\begin{array}{l}\text { Reasonable to prefer } \\
\text { ticagrelor over clopidogrel } \\
\text { in patients after coronary } \\
\text { stent implantation or in } \\
\text { those who have not }\end{array}$ & Class IIa \\
\hline & & & $\begin{array}{l}\text { undergone revascularization } \\
\text { or fibrinolysis }\end{array}$ & \\
\hline & $\begin{array}{l}\text { Prasugrel recommended } \\
\text { over clopidogrel in } \\
\text { patients proceeding to PCI } \\
\text { or in patients with a } \\
\text { STEMI undergoing } \\
\text { immediate coronary } \\
\text { angiography }\end{array}$ & Class I & $\begin{array}{l}\text { Reasonable to prefer } \\
\text { prasugrel over clopidogrel in } \\
\text { patients after coronary stent } \\
\text { implantation if no high-risk } \\
\text { of bleeding and no prior } \\
\text { history of stroke TIA. }\end{array}$ & Class IIa \\
\hline & $\begin{array}{l}\text { Clopidogrel } \\
\text { recommended for patients } \\
\text { having contraindications } \\
\text { for ticagrelor or prasugrel, } \\
\text { in those receiving oral } \\
\text { anticoagulation, or in } \\
\text { those treated with } \\
\text { fibrinolysis }\end{array}$ & Class I & $\begin{array}{l}\text { Clopidogrel recommended } \\
\text { in patients treated with } \\
\text { fibrinolysis or in those } \\
\text { receiving oral } \\
\text { anticoagulation }\end{array}$ & Class I \\
\hline \multirow[t]{2}{*}{$\begin{array}{l}\text { Short term } \\
\text { DAPT with } \\
\text { P2Y12- } \\
\text { antagonist }\end{array}$} & $\begin{array}{l}\text { In patients with high risk } \\
\text { of bleeding, consider } \\
\text { discontinuation after } 6 \\
\text { months }\end{array}$ & Class IIa & $\begin{array}{l}\text { Reasonable to discontinue } \\
\text { after } 6 \text { months in patients } \\
\text { who are at high risk for or } \\
\text { develop overt bleeding. }\end{array}$ & Class IIb \\
\hline & $\begin{array}{l}\text { Consider discontinuation } \\
\text { after 1month in case of } \\
\text { elective non-cardiac } \\
\text { surgery, regardless of the } \\
\text { stent type if aspirin can be } \\
\text { continued perioperatively }\end{array}$ & Class IIa & & \\
\hline \multirow[t]{2}{*}{$\begin{array}{l}\text { Long term } \\
\text { DAPT with } \\
\text { P2Y12- } \\
\text { antagonist }\end{array}$} & $\begin{array}{l}\text { In patients who have } \\
\text { tolerated DAPT without } \\
\text { bleeding risk for } 12 \\
\text { months, consider } \\
\text { continuation (upto } 36 \\
\text { months) }\end{array}$ & Class IIb & $\begin{array}{l}\text { Reasonable to continue for } \\
\text { longer than } 12 \text { months ( } 18- \\
24 \text { months) in patients who } \\
\text { have tolerated DAPT } \\
\text { without bleeding } \\
\text { complications, and are not at } \\
\text { high bleeding risk }\end{array}$ & Class IIb \\
\hline & $\begin{array}{l}\text { Preferable to use } \\
\text { Ticagrelor } 60 \mathrm{mg} \mathrm{BD}, \\
\text { over clopidogrel or } \\
\text { prasugrel in patients at } \\
\text { high ischaemic risk }\end{array}$ & Class IIb & & \\
\hline Aspirin & $\begin{array}{l}75-100 \text { mg daily MD } \\
\text { recommended indefinitely } \\
\text { for all patients. }\end{array}$ & Class I & $\begin{array}{l}\text { 75-100 mg daily MD with } \\
\text { P2Y12 antagonist, } \\
\text { recommended indefinitely } \\
\text { for all patients. }\end{array}$ & Class I \\
\hline
\end{tabular}

$L D$ loading dose, $M D$ maintenance dose, $A C S$ acute coronary syndrome, $P C I$ per cutaneous intervention, STEMI ST elevation myocardial infarction, $T I A$ transient ischemic attack, $D A P T$ dual anti platelet therapy, $B D$ twice a day, $O D$ once daily 
(Academic Research Consortium) HBR identified Twenty clinical criteria as major or minor by consensus, supported by published evidence. Patients are considered to be at HBR if at least one major or two minor criteria are met [28].

\section{Combination of Antiplatelet And Anti- Thrombotic Therapies}

Patients with ACS and atrial fibrillation (AF) have indication for use of Oral anti-Coagulant (OAC) along with DAPT. This combination is called "triple therapy". Such therapy has a two- to threefold increase in bleeding compared to DAPT and an assessment to balance ischemic risk and bleeding risk requires patient-by-patient decisions [29]. Strategies to avoid bleeding complications in such patients include proper assessment of bleeding risks with validated risk predictors like the HAS-BLED score, keeping triple therapy as short as possible, consider dual therapy with OAC with clopidogrel (preferred) instead of triple therapy, consider use of novel OACs instead of Vit-K antagonists when not contraindicated, usage of low-dose aspirin when required ( $<100 \mathrm{mg}$ daily) and routine use of PPIs [30].

As expected, bleeding is one of the adverse events encountered during antiplatelet therapy. Chances of bleeding increase when it is used as a combination like in DAPT and triple therapy. Gastrointestinal bleeding is one of the most common and life-threatening complications of DAPT [31]. The presence of certain risk factors like increasing age, female sex, Helicobacter pylori infection, diabetes, hypertension, other major organ dysfunctions and prior history of bleeding disorders can increase risk for GI bleed [32]. Occurrence of GI bleed in ACS patients receiving DAPT increases the risk of ischemic events by releasing catecholamines and increasing platelet adhesiveness [33]. It is also associated with longer hospital stays and early mortality [34].

In the case of occurrence of GI bleeds, it needs to be managed on an emergency basis with blood transfusions and endoscopic hemostasis. It may require premature termination of DAPT, at the cost of increased ischemic risks. However, an RCT by Sung et al. showed that there is an increased risk of recurrent bleeding on resumption of low-dose aspirin after endoscopic hemostasis, but 8-week mortality was significantly lower (1.3 vs. $12.9 \%$ with placebo) [35]. PPI prophylaxis is recommended in patients with increased risk of GI bleed, as it is associated with a substantial decrease in risk of upper GI bleed and effective in preventing rebleeding. Therefore, in order to avoid further ischemic events, it is advisable to resume antiplatelet therapy with PPI co-therapy immediately after the successful endoscopic control of GI bleed [36]. Management of bleeding with triple therapy is summarized in Table 3 [30].

\section{Variations in Response to Therapies}

There is marked variation in the response to therapies in different regions of the world. A higher prevalence of high on treatment platelet reactivity in East Asian patients included in the pivotal trials for antiplatelet drugs. However, the thrombotic rates after PCI were similar or lower in this subgroup than the western population. This contradicting feature is commonly referred to as the "East Asian Paradox" [37]. Even though few patients respond poorly to antiplatelet agents, currently there are no recommendations for platelet function testing as RCTs that used platelet function guided therapy showed neutral results [38].

Considering these differences among ethnic groups, the World Heart Federation brought out a Consensus Statement on Antiplatelet Therapy in East Asian Patients with ACS or Undergoing PCI after evaluating guidelines from different East Asian countries [37]. The consensus noted that there was not much difference in recommendations for aspirin use in East Asian patients or undergoing PCI from those of ACC/ AHA and ESC guidelines. The clinical trials that support the use of P2Y12 inhibitors included only a small number of East Asian patients. The prevalence of STEMI in East Asian countries is higher than NSTEMI, which might impact the treatment strategy. The consensus concluded that use of clopidogrel and aspirin is a reasonable first choice DAPT in East Asian patients with ACS or undergoing PCI, and routine testing of platelet function is not recommended in 
patients receiving DAPT. Further trials are needed to establish superiority of prasugrel and Ticagrelor over clopidogrel in East Asian population [37].

Major treatment guidelines (supported by class I evidence) are largely adopted within Asia. These guidelines consistently recommend the use of ticagrelor in ACS patients. Unlike clopidogrel, ticagrelor is not influenced by CYP2C19 polymorphism, for which there is a high prevalence of loss-of-function in Asian populations [39].

\section{Guideline Recommendations}

Table 4 summarizes the important guideline recommendations [40, 41].

\section{CONCLUSIONS}

Interpreting the evidence in the rapidly progressing field of antiplatelet therapy can be challenging. While clopidogrel laid the foundation for DAPT and revolutionized the management of ACS, the delayed onset of action, variable on-treatment platelet reactivity, and suboptimal prevention of recurrent ischemic events with clopidogrel paved the way for more potent P2Y12 antagonists. Newer P2Y12 antagonists prasugrel and ticagrelor with more potent and consistent antiplatelet effects have demonstrated superiority in terms reduction in the risk of the primary composite endpoint (CV death, non-fatal MI, or stroke) when administered for 12 months $[10,12]$. The current guidelines recommend use of DAPT for 12 months in all patients with ACS, however, as in all areas of medicine, an individual assessment is required. A detailed summary of important trials of DAPT to date has been included in the summary appendix.

\section{ACKNOWLEDGEMENTS}

Funding. No funding or sponsorship was received for this study. The Rapid Service Fees were funded by AstraZeneca.
Medical Writing Assistance. The authors thank AstraZeneca Pharma India Ltd for providing medical writing assistance in the development of this manuscript.

Authorship. All named authors meet the International Committee of Medical Journal Editors (ICMJE) criteria for authorship for this article, take responsibility for the integrity of the work as a whole, and have given their approval for this version to be published.

Disclosures. Dr. Prashanth and Dr. Yogesh are employees of AstraZeneca. Dr. Raghav Sharma and Dr. Prathap Kumar have nothing to declare.

Compliance with Ethics Guidelines. This article is based on previously conducted studies and does not contain any studies with human participants or animals performed by any of the authors.

Open Access. This article is licensed under a Creative Commons Attribution-NonCommercial 4.0 International License, which permits any non-commercial use, sharing, adaptation, distribution and reproduction in any medium or format, as long as you give appropriate credit to the original author(s) and the source, provide a link to the Creative Commons licence, and indicate if changes were made. The images or other third party material in this article are included in the article's Creative Commons licence, unless indicated otherwise in a credit line to the material. If material is not included in the article's Creative Commons licence and your intended use is not permitted by statutory regulation or exceeds the permitted use, you will need to obtain permission directly from the copyright holder. To view a copy of this licence, visit http://creativecommons.org/licenses/by$\mathrm{nc} / 4.0 /$.

\section{REFERENCES}

1. Chan MY, Du X, Eccleston D, et al. Acute coronary syndrome in the Asia-Pacific region. Int J Cardiol. 2016;1(202):861-9. 
2. Vedanthan R, Seligman B, Fuster V. Global perspective on acute coronary syndrome: a burden on the young and poor. Circ Res. 2014;114(12):1959-75. https://doi.org/10.1161/CIRCRESAHA.114.302782.

3. Ohira T, Iso H. Cardiovascular disease epidemiology in Asia. Circ J. 2013;77(7):1646-52.

4. Wilson SJ, Newby DE, Dawson D, et al. Duration of dual antiplatelet therapy in acute coronary syndrome. Heart. 2017;103(8):573-80.

5. Degrauwe S, Pilgrim T, Aminian A, et al. Dual antiplatelet therapy for secondary prevention of coronary artery disease. Open Heart. 2017;4(2): e000651.

6. PLAVIX ${ }^{\circledR}$ (clopidogrel bisulfate) tablets [package insert on the Internet]. Bridgewater, (NJ): SanofiAventis. 1997. https://packageinserts.bms.com/pi/ pi_plavix.pdf. Accessed 11 Sep 2018.

7. Effient ${ }^{\circledR}$ (prasugrel) tablets [package insert on the Internet]. Indianapolis (IN): Eli Lilly. 2009. https:// pi.lilly.com/us/effient.pdf. Accessed 11 Sep 2018.

8. BRILINTA ${ }^{\circledR}$ (ticagrelor) tablets [package insert on the Internet]. Wilmington (DE): AstraZeneca Pharmaceuticals. 2011. https://www.accessdata.fda.gov/ drugsatfda_docs/label/2016/022433s020lbl.pdf. Accessed 11 Sep 2018.

9. Biasco L, Montrasio G, Moccetti M, Pedrazzini G. Current trends in dual antiplatelet therapy: a 2017 update. Cardiovasc Med. 2017;20(7-8):169-75.

10. Wiviott SD, Braunwald E, McCabe CH, et al. Prasugrel versus clopidogrel in patients with acute coronary syndromes. N Engl J Med. 2007;357: 2001-155.

11. Wiviott SD, White HD, Ohman EM, Fox KA, et al. Prasugrel versus clopidogrel for patients with unstable angina or non-ST-elevation myocardial infarction with or without angiography: a secondary, prespecified analysis of the TRILOGY ACS trial. Lancet. 2013;382:605-13.

12. Wallentin L, Becker RC, Budaj A, et al. Ticagrelor versus clopidogrel in patients with acute coronary syndromes. N Engl J Med. 2009;361:1045-57.

13. Pareek M, Bhatt D. Dual antiplatelet therapy in patients with an acute coronary syndrome: up to 12 months and beyond. Eur Heart J Suppl. 2018;20(suppl B):B21-B2828.

14. Rapsomaniki E, Thuresson M, Yang E, et al. Using big data from health records from four countries to evaluate chronic disease outcomes: a study in 114,364 survivors of myocardial infarction. Eur Heart J. 2016;2(3):172-83.
15. Bhatt D, Fox K, Hacke W, et al. Clopidogrel and aspirin versus aspirin alone for the prevention of atherothrombotic events. Am J Ophthalmol. 2006;142(2):366.

16. Bonaca MP, Bhatt DL, Cohen M, et al. PEGASUSTIMI 54 Steering Committee and Investigators. Long-term use of ticagrelor in patients with prior myocardial infarction. N Engl J Med. 2015;372(19): 1791-800.

17 Mauri L, Kereiakes DJ, Yeh RW, DAPT Study Investigators, et al. Twelve or 30 months of dual antiplatelet therapy after drug-eluting stents. N Engl J Med. 2014;371(23):2155-66.

18. Watanabe H, Domei T, Morimoto T, et al. Effect of 1-month dual antiplatelet therapy followed by clopidogrel vs 12-month dual antiplatelet therapy on cardiovascular and bleeding events in patients receiving PCI: The STOPDAPT-2 randomized clinical trial. JAMA. 2019;321(24):2414-27. https://doi. org/10.1001/jama.2019.8145.

19. Hahn J, Song YB, Oh J, et al. Effect of P2Y12 inhibitor monotherapy vs dual antiplatelet therapy on cardiovascular events in patients undergoing percutaneous coronary intervention: the SMARTCHOICE randomized clinical trial. JAMA. 2019;321(24):2428-37. https://doi.org/10.1001/ jama.2019.8146.

20. Vranckx P, Valgimigli M, Jüni P, GLOBAL LEADERS Investigators, et al. Ticagrelor plus aspirin for 1 month, followed by ticagrelor monotherapy for 23 months vs aspirin plus clopidogrel or ticagrelor for 12 months, followed by aspirin monotherapy for 12 months after implantation of a drug-eluting stent: a multicentre, open-label, randomised superiority trial. Lancet. 2018. https://doi.org/10.1016/S01406736(18)31858-0.

21. Mehran R, Baber U, Sharma S, et al. Ticagrelor with or without aspirin in high-risk patients after PCI. N Engl J Med. 2019;381(21):2032-42.

22. Kim B, Hong S, Cho Y, et al. Effect of ticagrelor monotherapy vs ticagrelor with aspirin on major bleeding and cardiovascular events in patients with acute coronary syndrome: the TICO randomized clinical trial. JAMA. 2020;323(23):2407-16. https:// doi.org/10.1001/jama.2020.7580.

23. Steg P, Bhatt D, Simon T, et al. Ticagrelor in patients with stable coronary disease and diabetes. N Engl J Med. 2019;381(14):1309-20.

24. Bhatt D, Steg P, Mehta S, et al. Ticagrelor in patients with diabetes and stable coronary artery disease with a history of previous percutaneous coronary intervention (THEMIS-PCI): a phase 3, placebo- 
controlled, randomised trial. Clin Trial. 2019. https://doi.org/10.1016/S0140-6736(19)31887-2.

25. Motovska Z, Hlinomaz O, Miklik R, et al. Prasugrel versus ticagrelor in patients with acute myocardial infarction treated with primary percutaneous coronary intervention. Circulation. 2016;134(21): 1603-12.

26. Schüpke S, Neumann F, Menichelli M, et al. Ticagrelor or prasugrel in patients with acute coronary syndromes. N Engl J Med. 2019;381(16):1524-34.

27. Zhao X, Li J, Tang X, et al. Prognostic value of the PARIS thrombotic risk score for 2-year mortality after percutaneous coronary intervention. Clin Appl Thromb Hemost. 2019;25: $1076029619853638 . \quad$ https://doi.org/10.1177/ 1076029619853638 .

28. Urban P, Mehran R, Colleran R, et al. Defining high bleeding risk in patients undergoing percutaneous coronary intervention. Circulation. 2019;140(3): 240-61. https://doi.org/10.1161/ CIRCULATIONAHA.119.040167.

29. Lamberts M, Gislason GH, Olesen JB, Kristensen SL, Schjerning Olsen AM, Mikkelsen A, Christensen CB, Lip GY, Kober L, Torp-Pedersen C, Hansen ML. Oral anticoagulation and antiplatelets in atrial fibrillation patients after myocardial infarction and coronary intervention. J Am Coll Cardiol. 2013;62: 981-9.

30 Neumann FJ, Sousa-Uva M, Ahlsson A, et al. 2018 ESC/EACTS Guidelines on myocardial revascularization. Eur Heart J. 2019;40(2):87-165. https://doi. org/10.1093/eurheartj/ehy394.

31. Yasuda H, Yamada M, Sawada S, Endo Y, Inoue K, Asano F, Takeyama Y, Yoshiba M. Upper gastrointestinal bleeding in patients receiving dual antiplatelet therapy after coronary stenting. Intern Med. 2009;48:1725-30.

32. Chin MW, Yong G, Bulsara MK, Rankin J, Forbes GM. Predictive and protective factors associated with upper gastrointestinal bleeding after percutaneous coronary intervention: a case-control study. Am J Gastroenterol. 2007;102:2411-6.

33. Eikelboom JW, Mehta SR, Anand SS, Xie C, Fox KA, Yusuf S. Adverse impact of bleeding on prognosis in patients with acute coronary syndromes. Circulation. 2006; 114:774-82.

34. Nikolsky E, Stone GW, Kirtane AJ, Dangas GD, Lansky AJ, McLaurin B, Lincoff AM, Feit F, Moses JW, Fahy $M$, et al. Gastrointestinal bleeding in patients with acute coronary syndromes: incidence, predictors, and clinical implications: analysis from the ACUITY (Acute Catheterization and Urgent
Intervention Triage Strategy) trial. J Am Coll Cardiol. 2009;54:1293-302.

35. Sung JJ, Lau JY, Ching JY, Wu JC, Lee YT, Chiu PW, Leung VK, Wong VW, Chan FK. Continuation of low-dose aspirin therapy in peptic ulcer bleeding: a randomized trial. Ann Intern Med. 2010;152:1-9.

36. Yasuda H, Matsuo Y, Sato Y, et al. Treatment and prevention of gastrointestinal bleeding in patients receiving antiplatelet therapy. World J Crit Care Med. 2015;4(1):40-6. https://doi.org/10.5492/ wjccm.v4.i1.40.

37. Levine GN, Jeong YH, Goto S, et al. World Heart Federation expert consensus statement on antiplatelet therapy in East Asian patients with ACS or undergoing PCI. Glob Heart. 2014;9(4):457-67. https://doi.org/10.1016/j.gheart.2014.08.001.

38. Floyd CN. Dual antiplatelet therapy in coronary artery disease: comparison between ACC/AHA 2016 and ESC 2017 guidelines. Eur Cardiol. 2020;15:1-3. https://doi.org/10.15420/ecr.2019.09.

39. Asia-Pacific ACS Medical Management Working Group, Huo Y, Thompson P, et al. Challenges and solutions in medically managed ACS in the AsiaPacific region: expert recommendations from the Asia-Pacific ACS Medical Management Working Group. Int J Cardiol. 2015;183:63-75. https://doi. org/10.1016/j.ijcard.2014.11.195.

40. Levine GN, Bates ER, Bittl JA, Brindis RG, et al. 2016 ACC/AHA guideline focused update on duration of dual antiplatelet therapy in patients with coronary artery disease: a report of the American College of Cardiology/American Heart Association Task Force on clinical practice guidelines: an update of the 2011 ACCF/AHA/SCAI guideline for percutaneous coronary intervention, 2011 ACCF/AHA guideline for coronary artery bypass graft surgery, $2012 \mathrm{ACC} /$ AHA/ACP/AATS/PCNA/SCAI/STS guideline for the diagnosis and management of patients with stable Ischemic heart disease, 2013 ACCF/AHA guideline for the management of ST-elevation myocardial infarction, 2014 AHA/ACC guideline for the management of patients with Non-ST-elevation acute coronary syndromes, and 2014 ACC/ AHA guideline on perioperative cardiovascular evaluation and management of patients undergoing noncardiac surgery. Circulation. 2016;134(10): e123-e155155.

41. Valgimigli M, Bueno H, Byrne RA, et al. 2017 ESC focused update on dual antiplatelet therapy in coronary artery disease developed in collaboration with EACTS: The Task Force for dual antiplatelet therapy in coronary artery disease of the European Society of Cardiology (ESC) and of the European Association for Cardio-Thoracic Surgery (EACTS). Eur Heart J. 2018;39(3):213-60. 